\title{
REVIEW
}

\section{Immunological evaluation of cytokine and anticytokine immunotherapy in vivo: what have we learnt?}

\author{
Christian Jorgensen, Florence Apparailly, Jacques Sany
}

Over the past five years, several immunotherapy trials have been performed in autoimmune diseases by targeting interleukin $1 \beta$ (IL1 $\beta$ ) (IL1 receptor antagonist (IL1-ra), IL-1 type I receptor), tumour necrosis factor $(\mathrm{TNF} \alpha)$ (mAb anti-TNF $\alpha$, soluble receptor RTNFp55 or $\mathrm{p} 75$ fusion protein, TNF binding protein), interleukin 6 (IL6) or Th2 cytokines like recombinant human interleukin 10 (rhuIL10) (table 1). ${ }^{1}$ One limitation of attempts to target a single cytokine is the overlap of the immune effects of IL1, TNF $\alpha$, and IL6. However, the clinical trials indicate that inhibition of a single cytokine, despite the complexity of the network, is efficient. Moreover, the inhibition of major cytokines involved in host defence was found to be relatively well tolerated in the short-term, and few infections were reported. Paradoxically, very few data are available concerning effects of systemic delivery of rhuIL10 or cytokine antagonist on the immune system. This review analyses the available data on in vivo modification of the immune response after targeting a single cytokine (IL1 $\beta, \mathrm{TNF} \alpha$, IL6 or IL10) in RA, and to extrapolate on combined biotherapeutic

The immunopathology of RA synovitis is now better understood, and mediators of joint inflammation to be targeted have been identified. Whatever the initial antigenic stimulation, the proinflammatory cytokines IL $1 \beta, T N F \alpha$ and IL6 play a pivotal part in all phases of rheumatoid arthritis (RA) disorder. The autoimmune process in RA may be arbitrarily subdivided into three chronological phases: the early inflammation phase, synovial prolifera-

Correspondence to: Dr Jorgensen. regimens.

tion and pannus formation in the chronic phase, cartilage degradation and repair in the last phase. At the early phase, memory CD45Ro $T$ cells are attracted into the joint through a cascade of adhesion molecules induced by IL $1 \beta / \mathrm{TNF} \alpha$ and activated locally. IL6 and TNF $\alpha$ induce monocyte differentiation into dendritic cells CD14- CD83+ (DC). Macrophages and DC have a key role in the immune process and contribute to $\mathrm{T}$ cell activation as antigen presenting cells. Interleukin 10 inhibits in vitro the differentiation of monocytes to DC and promotes macrophage maturation. ${ }^{2}$ In the chronic phase of the disease, synovial monocytes produce large amounts of cytokines, angiogenic growth factors and chemoattractive molecules inducing synovial cell proliferation, angiogenesis, and pannus formation and mononuclear cell infiltration. ${ }^{3}$ During this phase, type B synovial cells proliferate independently of T cells as they lose their apoptotic properties. In the last phase of the disease, the release of large amounts of proinflammatory cytokines and metalloproteases by synoviocytes and monocytes (collagenase, stromelysine, gelatinase) contributes to cartilage degradation. Despite the production of Th2 cytokines (IL4, IL10) and TGF $\beta$, the cytokine balance in the cartilage tissue favours cartilage matrix resorption, synovial inflammation and bone cyst formation. Most proinflammatory cytokines are produced simultaneously by multiple cell types. They have pleiotropic biological effects with substantial overlap and synergise. These proinflammatory cytokines might be optimal therapeutic target for RA, but the consequences on the immune system (host defence, lymphocytes subset and Th1/Th2 phenotype, blood monocyte activity) remains unexplored.

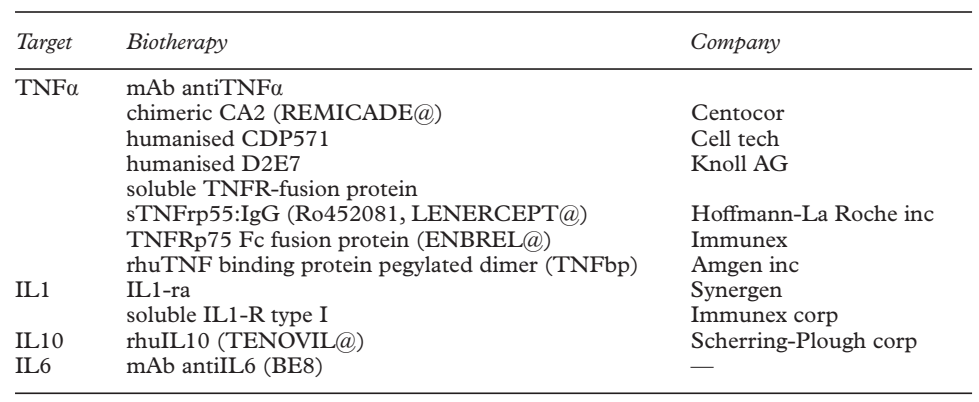

Treatment with recombinant human IL10 (rhuIL10)

IL10 is a $35 \mathrm{kDa}$ peptide initially described as "cytokine synthesis inhibitory factor" because of its ability to suppress cytokine synthesis in Th1 cells. In vitro, IL10 inhibits proinflammatory secretion of cytokines such as IL1 $\beta$, TNF $\alpha$, IL6, GM-CSF. ${ }^{3}$ Moreover, IL10 reduces MHC class II cell expression on 
monocytes, induces $\mathrm{T}$ cell energy and decreases the expression of adhesion molecules. Finally, IL10 inhibits metalloprotease secretion and induces the metalloprotease inhibitor TIMP-1 on monocytes. ${ }^{5}$ On in vitro RA synovial tissue, endogenous IL10 downregulates $\mathrm{TNF} \alpha$ and IL1 $\beta$ production. ${ }^{6}$ When stimulation of synovial cells with interferon gamma is undertaken, IL1 $\beta$ markedly increased the expression of costimulatory molecules and cytokine production. Both spontaneous and upregulated costimulatory molecule expression and cytokine production were significantly suppressed by the addition of rhuIL $10{ }^{7}$

Preclinical studies in murine collagen induced arthritis with recombinant murine IL10 in the early phase of the disease were shown to inhibit foot pad swelling and the number of affected paws. ${ }^{8}$ A protective effect on cartilage degradation was observed the treated mice. This protection is in part linked to the suppression of both TNF $\alpha$ and IL1 production, and to upregulation of IL1ra. Systemic IL10 gene transfer in murine CIA immediately after the onset of the disease resulted in decrease in the paw swelling and the clinical score. ${ }^{9}$ An increase in the $\operatorname{IgG} 2 \mathrm{a} / \mathrm{IgG} 1$ ratio of anti collagen II antibody suggests that IL10 therapy induced a Th2 shift. The invasive properties of human RA synovial tissue in cartilage engrafted in SCID mice was inhibited by persistent IL10 secretion obtained either by intrasynovial rhuIL1 0 injection or by cytokine gene transfer..$^{11}$

In humans, systemic administration of rhuIL10 resulted in marked monocyte depression. Seventeen healthy volunteers received 1 , 10 or $25 \mu \mathrm{g} / \mathrm{kg}$ rhuIL $10 .{ }^{12}$ An increase in the blood monocyte count was observed three hours after infusion and persisted for 24 hours in the high dose group. Endotoxin induced IL1 and $\mathrm{TNF} \alpha$ production by monocytes was inhibited in all treated patients independent of the IL10 dose. Three patients with psoriasis were treated with rhuIL10 $(8 \mu \mathrm{g} / \mathrm{kg}) .^{13}$ In contrast with the first study, no significant increase in the absolute number of monocytes was noted, but a suppression of DR expression on monocytes as well as a decrease in IL12 p40 subunit plasma concentrations in the patients indicated immunosuppression of blood monocytes. Two clinical conditions (sepsis and brain injury) are associated with high serum concentrations of IL10 and have highlighted the immunosuppressive effects on blood monocytes. In these cases of intense inflammation, endogenous IL10 is produced to counterbalance the excessive immune response. In sepsis, the human plasma contains up to $19000 \mathrm{pg} / \mathrm{ml} \mathrm{IL10}$, and this cytokine was shown

Table 2 Immune consequence of cytokine/anticytokine treatment in human trials

\begin{tabular}{lllll}
\hline & IL10 & $\begin{array}{l}\text { TNFa } \\
\text { inhibition }\end{array}$ & $\begin{array}{l}\text { IL1 } \\
\text { inhibition }\end{array}$ & IL6 inhibition \\
\hline lymphocytes count & $\searrow$ (transient) & $\nearrow$ & no change & $\searrow$ (transient) \\
CD4/CD8 ratio & no change & no change & no change & no change \\
T cell response & $\searrow$ (anergy) & $\nearrow$ & $\searrow$ & $?$ \\
Th/Th2 shift & $\rightarrow$ Th2 & $?$ & $?$ & $?$ \\
monocytes count & $\nearrow$ & $?$ & no change & $?$ \\
monocytes activity & $\searrow$ & $?$ & $?$ \\
blood monocytes DR expression & $\searrow$ & no change & no change & $?$ \\
\hline
\end{tabular}

to be responsible for inhibition of monocyte production of TNF $\alpha$ and IL6 ex vivo $(0 \%$ and $4 \%$ respectively compared with $100 \%$ in controls). ${ }^{14}$ Serum IL10 increased up to 200 $\mathrm{pg} / \mathrm{ml}$ in cases of brain injury with high intracranial pressure. In these patients, a decrease in DR expression by monocytes was observed $(26 \pm 4 \%$ decrease from baseline). ${ }^{15}$ DR expression was restored ex vivo by a IL10 neutralising monoclonal antibody $(\mathrm{mAb})$. Moreover, in the same pathological conditions, $\mathrm{TNF} \alpha$ secretion by monocytes after endotoxin stimulation decreased by $50 \%$ (from $2.98 \pm 1$ to $1.47 \pm 1 \mathrm{ng} / \mathrm{ml}$ ).

Recombinant human IL10 is currently being tested in human autoimmune diseases (RA, Crohn's decease, multiple sclerosis). Seventy two patients with RA have been treated with rhuIL10 doses ranging from 1 to 20 $\mu \mathrm{g} / \mathrm{kg} /$ day. ${ }^{16}$ The treatment tolerance was acceptable, the major side effect was a moderate central thrombopenia in less than $5 \%$ of patients in the high dose group. Clinical improvement of RA was observed in the 5 $\mu \mathrm{g} / \mathrm{kg}$ group, and not in the $20 \mu \mathrm{g} / \mathrm{kg} /$ day group. This difference might be explained either by a paradoxical immunostimulant effect of IL10 on CD8 cells as previously described, or by a down regulation of IL10-R expression by target cells. Few immunological data are available in rhu-treated RA patients. A trend towards decreased production of ex vivo induced proinflammatory cytokines (TNF $\alpha, \operatorname{IL} 1 \beta)$ and increased circulating serum concentrations of soluble $\mathrm{TNF} \alpha \mathrm{p} 55 / \mathrm{p} 75$ receptors was noted in all rhuIL10 treated patients. A decrease in HLA DR expression by monocytes was observed at day 28 after rhuIL10 treatments ( 8 $\mu \mathrm{g} / \mathrm{kg}$ ), without changing the number of CD14 cells. ${ }^{13}$ Chernoff et al showed a $50 \%$ decrease in both CD 4 and CD8 subtype after a single rhuIL10 infusion. ${ }^{12}$ The absolute number of blood $\mathrm{T}$ cells was normalised within 24 hours. No details concerning their functional activity were described. An antigen specific immunotherapy in allergic people allows the evaluation of IL 10 on T cell function. In bee venom allergic patients, specific immunotherapy resulted in IL10 production by blood $\mathrm{T}$ cells and monocytes in vivo. ${ }^{17}$ The number of IL10 producing monocytes increased from $1.2 \%$ to $42 \% 28$ days after desensitisation. T cell energy was induced in vivo, and could be reestablished by neutralisation of endogenous IL10 ex vivo. Moreover, a shift in the Th1/Th2 profile was observed after specific immunotherapy, and correlated with an increase in IL10 producing $\mathrm{T}$ cells. These results were confirmed in psoriasis patients treated with daily rhIL10 after Th1/Th2 profile evaluation. ${ }^{13}$ The percentage of IL4 and IL10 producing $\mathrm{T}$ cells increased in all patients after day 2 , and persisted to day 24 . The ratio of IFN $\gamma /$ IL4 producing T cells decreased during the four week observation period.

The most important immune consequences in vivo after daily rhIL10 are the shift in the Th1/Th2 $\mathrm{T}$ cell phenotype and the inhibition of blood monocytes and $\mathrm{T}$ cell anergy (table 2 ). 
Immunotherapy targeting $\mathbf{T N F} \alpha$

$\mathrm{TNF} \alpha$ is a key cytokine in RA, with pleitropic properties relevant to the pathogenesis of the disease. These include induction of synovial production of other inflammatory cytokines (such as IL1 $\beta$, IL6), expression of adhesion molecules and activation of endothelial cells (reviewed by Maini et $a l^{18}$ ). Transgenic mice containing human $\mathrm{TNF} \alpha$ 3' modified gene expressed high levels of huTNF $\alpha$ in vivo and spontaneously developed arthritis, beginning at 4 weeks of age. $\mathrm{TNF} \alpha$ blockade has been extensively studied in murine CIA. The disease was prevented by administration of $\mathrm{mAb}$ to huTNF $\alpha$ before arthritis onset. Moreover, collagen induced arthritis was significantly improved and tissue destruction decreased when hamster $\mathrm{mAb}$ antimurine $\mathrm{TNF} \alpha(\mathrm{TN} 3.19 .2)$ was administered over a 10 day period immediately after disease onset. IgG anticollagen antibodies was not modified, and $\mathrm{TNF} \alpha$ inhibition resulted in a decrease in IL1 and IL6 production. These results have prompted initiation of clinical trials in RA.

Neutralising $\mathrm{TNF} \alpha$ was initially achieved through chimeric monoclonal antibodies. Double blind multicentre randomised placebo controlled trials performed with the chimeric $\mathrm{mAb}$ (CA2) in patients with active RA have been completed, and provided evidence that specific $\mathrm{TNF} \alpha$ blockade was indeed effective. ${ }^{19}$ The duration of the clinical response is often no greater than a few weeks and, although repeated treatments appear efficient, immunisation to CA2 may ultimately limit the use of the mAb. ${ }^{20}$ Alternative treatments combining CA2 and methotrexate have been proposed showing a synergistic clinical response with a decrease in immunisation against CA2. ${ }^{21}$ Fully humanised monoclonal antibodies are now available and seem to be as effective. One hundred and twenty RA patients have been included in a multicentre trial with dose ranging up to 10 $\mathrm{mg} / \mathrm{kg}$ of the $\mathrm{mAb}$ D2E7. After one intravenous infusion, $78 \%$ of the patients in the high dose group had a significant clinical response. ${ }^{22}$ To optimise $\mathrm{TNF} \alpha$ neutralisation, engineered molecules have been designed to bind two TNF molecules. A pegylated dimeric $\mathrm{TNF} \alpha$ binding protein have been evaluated in a phase I/II study and seemed to be safe. ${ }^{23}$ Two dimeric soluble TNF-receptors combined with the $\mathrm{Fc}$ of a human immunoglobulin have been developed: sTNF rp55:IgG (Ro452081, Lenercept) and TNFRp75:FC fusion protein (Enbrel), this last molecule being approved by the FDA for the treatment of RA. The results of a multicentre phase III clinical trial including 234 RA patients with TNFRp75:FC confirmed the efficiency of this molecule. ${ }^{24}$ In the group treated with $25 \mathrm{mg}$ subcutaneously twice weekly, 62 of 78 achieved the ACR20 response criteria, these results are impressive when compared with classic antirheumatic drugs.

In septic shock, $\mathrm{TNF} \alpha$ blockade through a $\mathrm{mAb}$ anti-TNFa or TNFRp55-Fc fusion protein did not demonstrate significant clinical benefit. A total of 498 patients with sepsis were randomised to receive a single infusion of p55$\operatorname{IgG}(0.083 / 0.042 / 0.008 \mathrm{mg} / \mathrm{kg}$ or placebo $) .{ }^{25} \mathrm{~A}$ trend toward a reduced mortality was noted day 28 (36\% reduction relative to controls). After the infusion of $7.5,15 \mathrm{mg} / \mathrm{kg}$ anti-TNF $\alpha$ $\mathrm{mAb}$ or placebo in 478 patients with septic shock, the mortality was $37.7,37.8$ or $45.5 \%$ respectively. ${ }^{26}$ Infusion of $\mathrm{TNF} \alpha$ in healthy volonteers rapidly causes transient neutropenia. ${ }^{27}$ An increase in the neutrophils would be expected as consequence of $\mathrm{TNF} \alpha$ inhibition. However, in the two latter studies in sepsis, no modification in the white cell count was observed and no immunological data are available, because of the impredictable and acute onset of this clinical situation.

Trials in RA patients are more informative concerning the immune effects of anti-TNF $\alpha$ treatment. The most patent immunological effect observed in vivo after anti-TNF $\alpha$ treatment in RA patients was a decrease in the number of blood monocytes. ${ }^{28}$ The immunological effect of TNF $\alpha$ blockade was evaluated at seven days after injection of $1 \mathrm{mg} / \mathrm{kg}(\mathrm{n}=6)$ or $10 \mathrm{mg} / \mathrm{kg}(\mathrm{n}=6)$ in RA patients. A decrease in the absolute number of blood monocytes was induced independently of the dose, but their was no significant modification of HLA-DR or CD25 expression by circulating monocytes. In this study, the concentration of IL1 $\beta$, IL6, and soluble CD14 (a marker of monocytes activity) decreased in the treated patients after seven days. Maini et al reported a dramatic decrease in the serum IL6 concentration after anti-TNF $\alpha$ infusion (from mean concentration of $60 \mathrm{pg} / \mathrm{ml}$ at baseline to 10 $\mathrm{pg} / \mathrm{ml}$ after 28 days)..$^{18}$ This decrease in IL6 resulted in a dramatic decrease in serum CRP. Paleolog et al treated 21 patients with $10 \mathrm{mg} / \mathrm{kg}$ of anti-TNF $\alpha$ (CA2) and observed a median decrease of $29 \%$ in the monocyte count. ${ }^{29}$ In parallel, serum soluble inter cellular adhesion molecule (sICAM-1) decreased by $29 \%$ at week 4 relative to baseline, but serum soluble vascular cell adhesion molecules (sVCAM-1) remained unchanged. Interestingly, these monocyte count changes were correlated with the clinical response.

After TNFa inhibition, the number of CD4+ and CD8+ lymphocytes increased the first day in the $1 \mathrm{mg} / \mathrm{kg}$ group, but not in the higher dose group. The number of $\mathrm{CD} 3+\mathrm{T}$ cells peaked on day 3 (maximum increase $53 \%$ ) and persisted for four weeks (median increase compared with baseline $36 \%){ }^{29} \mathrm{Be}-$ fore treatment, $\mathrm{T}$ cell response to mitogens was reduced in RA. The hyporesponsiveness of circulating immune cells to the CD28/PMA signal was normalised after CA2 infusion. ${ }^{28}$ This change was explained by an increase in the number of activated $\mathrm{T}$ cells in treated patients, which might be related to the inhibition of ICAM-1 expression in the synovial tissue. In the phase III Enbrel trial, DTH skin testing and immune cell subtype alteration were monitored in 49 patients at baseline and after two weeks, three months, and six months of treatment. ${ }^{30}$ No change were observed in the number of circulating monocytes, or in the CD3 blood lymphocytes. The activation markers (IL2-R expression) and adhesion molecules expression was not modified by TNFrp75:Fc 
administration. No functional change in the immune response was observed in vitro (cons stimulation) nor in vivo (DTH skin testing) after six months of treatment. Indeed, in the combination regimen of methotrexate and $\mathrm{CA} 2 \mathrm{mAb}$ in $\mathrm{RA}$, the number of infections requiring antibiotics were not statistically increased compared with the methotrexate group $\left(32.2 \%\right.$ v $21.4 \%$, NS). ${ }^{21}$

Emergence of anti-ds DNA antibodies in RA patients have been reported after anti-TNF $\alpha$ treatment. In the combination study with CA2 $\mathrm{mAb}, 8 \%$ of the patients developed IgM anti-dsDNA without clinical symptoms. Only one patient presented systemic lupus erythematosus (pleuropericarditis, fever and high titre IgG anti-dsDNA) three weeks after the last CA2 infusion. ${ }^{21}$ In contrast, only $2.9 \%$ (6 of 204) of RA patients in the Lenercept trial developed anti-dsDNA antibodies, while three of eight patients initially positive for anti-DNA became negative after treatment. ${ }^{31}$ The emergence of clinical lupus as a side effect has suggested that $\mathrm{TNF} \alpha$ inhibition might favour a Th2 profile. An indirect release of endogenous IL10 may stimulate B cells and favour plasmocytes differentiation and result in autoantibodies secretion. However, a shift in the Th1/Th2 CD 3 cells have not been reported in TNF neutralising studies in RA.

Immunohistological analysis of synovial biopsy specimens in 14 patients with RA was studied both before and four weeks after anti-TNF $\alpha$ mAb treatment. ${ }^{32}$ The patients either received a placebo $(n=2)$, or were given intravenous doses of CA2 at $10 \mathrm{mg} / \mathrm{kg}(\mathrm{n}=5)$ or $20 \mathrm{mg} / \mathrm{kg}(\mathrm{n}=7)$. A significant reduction in mean scores for $\mathrm{T}$ cells, adhesion molecules, vascular cell adhesion molecule 1 and E-selectin, was observed in synovial tissue relative to baseline after CA2 treatment. The reduced expression of adhesion molecules and the decreased cellularity of rheumatoid synovium after CA2 administration supports the hypothesis that the anti-inflammatory effect of anti-TNF $\alpha$ treatment could be partly explained by the down regulation of cytokine inducible vascular adhesion molecules in synovium, with a consequent reduction of immune cell traffic into joints. ${ }^{33}$ Thus TNF $\alpha$ neutralisation inhibits joint inflammation, decreased blood monocytes, and increased $\mathrm{T}$ cell number and activity. This therapeutic approach seems to be safe, but long term studies are needed.

\section{Immune consequence of IL1 blockade in} vivo

Evidence suggests that IL1 is an important mediator of inflammation and joint damage through cartilage resorption in experimental arthritis. ${ }^{34}$ IL $1 \beta$ induces prostaglandin $\left(\mathrm{PGE}_{2}\right)$ release by synovial cells and regulates the production of numerous cytokines involved in synovitis, such as IL2, IL4, IL10, IL5, IFN $\gamma$, and TNF $\alpha$. IL1 amplifies the $\mathrm{T}$ cell activation by inducing IL2 and IL2-receptor gene expression, but is not required for $\mathrm{T}$ cell proliferation. IL1 plays a central part in the Th1/Th2 shift. In IL1-receptor type I deficient mice, splenocytes and lymphnode cells produce increased amount of IL4 and IL10 after antigenic stimulation (fourfold and 10-fold increases respectively). ${ }^{29}$ These data demonstrate that IL1 negatively regulate IL4 and IL10 expression, and favours the Th1 response. Moreover, IL1 is a known activator of collagenase and stromelysin, an important step in cartilage breakdown. The effects of IL 1 are counterbalanced by the natural antagonist IL1 ra, membrane bound type II IL1 receptor and soluble IL1 receptors I and II. ${ }^{36}$ These two distinct receptors bind IL1 $\beta$ with distinct affinity and effects: the type 2 receptor does not induce intracellular signal transduction (decoy receptor), in contrast with the type 1 involved in IL1 biological effects. The soluble forms of both IL1 receptors contribute to the negative control of the immune response by trapping free IL1, but the type I receptor has a higher affinity for endogenous IL1ra thus exacerbating the inflammatory response.

Although IL1 and $\mathrm{TNF} \alpha$ have overlapping properties, each has distinct biological effects relevant to the pathogenesis of RA. In animal models of arthritis, blocking $\mathrm{TNF} \alpha$ or IL1 resulted in distinct effects. ${ }^{37}$ Anti-TNF $\alpha$ treatment showed efficacy on inflammation shortly after onset of the disease, but had little effect on fully established collagen induced arthritis. Anti-IL1 $\alpha / \beta$ treatment improved both early and full blown CIA. This clear suppression of established arthritis was confirmed by administration of high doses of IL-1 ra. ${ }^{37}$ Dose response experiments showed that a continuous supply of $1 \mathrm{mg} /$ day was needed for optimal suppression. Histological analysis showed markedly reduced cartilage destruction both in the knee and ankle joints. In this experimental work, autoradiographs with $\mathrm{S}^{35}$-sulphate demonstrated the recovery of chondrocyte synthesis function of articular cartilage after IL1 inhibition. Profound suppression of CIA was observed with anti-IL1 $\beta$, although elimination of both IL $1 \alpha$ and IL $1 \beta$ still gave better protection.

Both IL1 ra and sIL1 receptor type I have been proposed to suppress IL1 mediated inflammation in sepsis and RA. A randomised trial of 893 patients with sepsis were randomly assigned to receive one of two dose regimens of rhIL-1 ra $(1.0$ or $2.0 \mathrm{mg} / \mathrm{kg}$ per hour or placebo). ${ }^{38}$ During the treatment phase, all patients recieved an intravenous loading dose of rhIL-1 ra (100 mg) or vehicle. Infusion were well tolerated, but no clinical benefit was obtained in the treatment group: 34\% mortality (102 deaths out of 302 recipients of placebo) compared with $31 \%$ in the 1.0 $\mathrm{mg} / \mathrm{kg} / \mathrm{h}$ rhIL-1-ra treated patients and $29 \%$ among the $2.0 \mathrm{mg} / \mathrm{kg} / \mathrm{h}$ group. In this latter study no data on immune cells were available. In RA, 175 patients were randomised to receive 20,70 or $200 \mathrm{mg}$ IL-1 ra daily, three times a week or weekly. ${ }^{39}$ Overall tolerance was acceptable despite the fact that four patients developed infections. The lymphocyte CD4/CD 8 subsets were assessed by FACS analysis, and no modifications were reported. Moreover, no functional modifications of $\mathrm{T}$ cells were observed after mitogen stimulation experiments ex vivo. ${ }^{40}$ The efficiency of IL1 ra to slow cartilage degradation in RA was confirmed in 
an extension trial, where a decrease in the radiological progression was observed. ${ }^{41}$ An effect on haematopoesis could be expected as recombinant IL1 administration for 3-5 days $(0.001-1 \mu \mathrm{g} / \mathrm{kg})$ increased the neutrophil count and the platelets after five days of treatment. ${ }^{42}$ Indeed, IL1 inhibition resulted in significative neutropenia in $2 \%$ of the patients. ${ }^{39}$ Inhibition of IL1 may also be achieved through soluble type I or type II receptor. Intra-articular injection of sIL1 type I receptor have been performed in active knee arthritis, without clinical improvement. ${ }^{43}$ Twenty three RA patients received subcutaneously 125 to 1000 $\mu \mathrm{g} / \mathrm{m}^{2}$ IL-1R type I daily for 28 days. ${ }^{44}$ The absolute count of CD14 positive monocytes did not change during treatment, and CD25, DR and ICAM-1 expression was not modified after in vivo IL1 inhibition suggesting no change in the blood monocytes. The absolute CD3 cell count remained unchanged, but the $\mathrm{T}$ cell response to mitogens ex vivo was markedly inhibited after 28 days IL1 inhibition in the high dose group. No data concerning Th1/ Th2 balance were available in this latter study.

These trials confirm the efficiency of systemic IL $1 \beta$ or $\mathrm{TNF} \alpha$ blockade in a chronic autoimmune disease, with distinct effects on the immune system.

\section{Immune consequence of IL6 inhibition in RA}

IL6 is a $26 \mathrm{kDa}$ cytokine with shares most inflammatory effect with IL1 or TNF $\alpha$, and synergise with these cytokines to amplify the immune response. However, IL6 differs in its failure to stimulate $\mathrm{PGE}_{2}$ production by synoviocytes. Cumulative evidence have shown that IL6 is an important mediator for RA disease. IL6 increases osteoclasts activity in vitro and contributes significantly to bone resorbtion. IL6, in the presence of the agonistic receptor, induces synoviocytes proliferation. Recently, IL6 deficient mice IL6 -/- were shown to be protected against antigen induced arthritis. ${ }^{45}$ Most interestingly, articular cartilage was preserved in IL6 -/- mice despite a similar expression of IL1 and $\mathrm{TNF} \alpha \mathrm{mRNA}$ expression in the murine joints. These results indicate that IL6 might play a crucial part in cartilage resorption in experimental arthritis. The immune consequence of IL6 deficiency was evaluated in the animals. The CD4/CD8 ratio was not modified but a shift toward Th2 phenotype was observed: after Con A stimulation, a fivefold increase IL4 and IL10 production by lymph node cells was observed.

Five RA patients with seropositive, active disease were included in 1992 in an open pilot study with a mAb antill6 (BE8, IgG1). The patients received $10 \mathrm{mg} /$ day for 10 days. ${ }^{46}$ The treatment was well tolerated, and joint inflammation improved transiently in all patients. The immune evaluation was assessed through lymphocytes subset analysis before treatment and day $15,30,60,90$, and 123 after infusion. A moderate lymphopenia was observed day 60 (1200 v 2000 lymphocytes $/ \mathrm{mm}^{3}$ ), normalised day 60 but no modification in the CD4/CD8 ratio or DR expression was observed during six months of follow up.

There is a substantial potential for biological treatments targeting cytokines in RA. TNF neutralisation is now accessible in routine clinical practice. If this approach should be limited to severe and longstanding RA or to early disease, and if these biological therapeutics should be associated with methotrexate remain open questions. Cytokine delivery may be performed through systemic injection, biological osmotic pumps or gene therapy. ${ }^{47}$ Despite numerous clinical trials, our knowledge concerning the immunological effect of systemic administration of IL10 or inhibition of IL1 or TNFa is limited. Systemic injection of rhuIL10 seems to shift the T cell phenotype toward a Th2 response, and decrease monocyte function despite transient monocytosis. $\mathrm{TNF} \alpha$ blocking results in a decrease in the number of monocytes without changing their activity and without any suppressive effect on $\mathrm{T}$ cells. In contrast, IL1 inhibition seems to inhibit $\mathrm{T}$ cell functions without changing monocyte activity.

The combination of immunotherapy targeted on two cytokines to synergise the therapeutical effect in RA are currently discussed. The combination of murine rIL10 (5 $\mu \mathrm{g} /$ day) and anti-TNF $\alpha$ (300 $\mu \mathrm{g}$ the first day) in CIA resulted in an additive therapeutic effect and improved paw swelling at day 10 compared with the single $\mathrm{mAb}$ or cytokine therapy. Although not statistically significant, the combination regimen improved the histological joint score $(83 \%$ v $62 \%) .{ }^{48}$ A rational combination of cytokine immunotherapy may result in a synergic therapeutic effect, but a suitable immunological study of RA patients is required to assess the tolerance of such a regimen.

1 Moreland LW, Heck LW, Koopman WJ. Biological agents for treating rheumatoid arthritis. Arthritis Rheum 1997;40:397-409.

2 Allavena P, Piemonti L, Longoni D. IL10 prevents the differentiation of monocytes to dendritic cells but promotes their maturation to macrophages. Eur J Immunol 1998;28: 359-69.

3 Brennan FM, Maini R, Feldmann M. TNF alpha: a pivotal role in RA? Br J Rheumatol 1994;31:293-8.

4 De Waal-Malefyt R, Abrams B, Bennett B. IL10 inhibits cytokine synthesis by human monocytes. J Exp Med 1991; 174:1209-20

5 Lacraz S, Nicod L, Chicheportiche R, Welgus H, Dayer JM. IL10 inhibits metalloproteinase and stimulates TIMP-1 production in human mononuclear phagocytes. J Clin Invest 1995;96:2304-10.

6 Walmsley M, Katsikis P, Abney E, Parry S, Williams R, Maini R, et al. IL10 inhibition of the progression of established collagen-induced arthritis. Arthritis Rheum 1996; 39:495-503.

7 Katsikis PD, Chu C, Brennan FM, Maini R, Feldmann M. Immunoregulatory role of interleukin 10 in rheumatoid Immunoregulatory role of interleukin

8 Kawakami A, Eguchi K, Matsuoka N, Tsuboi M, Urayama $\mathrm{S}$, Kawabe Y, et al. Inhibitory effects of interleukin-10 on synovial cells of rheumatoid arthritis. Immunology 1997; 91:252-9.

9 Apparailly F, Verwaerde C, Jacquet C, Auriault C, Sany J, Jorgensen C. Adenovirus mediated transfer of viral IL10 gene inhibits murine collagen induced arthritis. J Immunol 1998;160:5213-20.

10 Jorgensen C, Apparailly F, Couret I, Canovas F, Jacquet C, Sany J. IL4 and IL10 are chondroprotective and decrease mononuclear cell recruitment in human rhumatoid synovium in vivo. Immunology 1998;93:518-23.

11 Jorgensen C, Apparailly F, Canovas F, Jacquet C, Sany J. IL10 gene transfer in human synovium engrafted in SCID mice. Arthritis Rheum (in press).

12 Chernoff AE, Granowitz E, Shapiro L, Vannier E, Lonnemann G, Angel JB, et al. A ransdomized, controlled trial of IL10 in humans. J Immunol 1995;154:5492-9. 
13 Asadullah K, Sterry W, Stephanek K, Jasulaitis D, Leupold $\mathrm{M}$, Audrig $\mathrm{H}$, et al. IL10 is a key cytokine in psoriasis. J Clin M, Audrig H, et al. IL10 is
Invest 1998;101:783-94.

14 Brandtzaeg P, Osnes L, Ovstebo R, Joo GB, Westvik A, Kierulf P. Net inflammatory capacity of human septic shock plasma evaluated by a monocyte based target cell assay: identification of IL10 as a major functionnal deacti-
vator of human monocytes. J Exp Med 1998;184:51-60.

15 Wociechowsky C, Asadullah K, Neseler D, Eberhardt B Platzer C, Schoning B, et al. Sympathetic activation triggers systemic interleukin-10 release in immunodepression induced by brain injury. Nature Medicine 1998;4:808-13

16 Maini RN, Paulus H, Breedveld FC, Charles P, Davies D, Grint P, et al. rHUIL10 in subjects with active rheumatoid arthritis: a phase I and cytokine response study. Arthritis Rheum 1997;40:S224.

17 Akdis C, Blesken T, Akdis M, Wuthrich B, Blaser K. Role of IL10 in specific immunotherapy. J Clin Invest 1998;102: 98-106.

18 Maini RN, Elliott MJ, Brennan FM, Williams RO, Chu C, Paleolog E, et al. Monoclonal anti-TNF alpha antibody as a probe of pathogenesis and therapy of rheumatoid disease. Immunol Rev 1995;144:195-223.

19 Elliott MJ, Maini RN, Feldmann M, Long-Fox A, Charles P, Katsikis $\mathrm{P}$, et al. Repeated therapy with monoclonal antibody to tumour necrosis factor alpha (cA2) in patients with rheumatoid arthritis. Arthritis Rheum 1993;36:1681-90.

20 Elliott MJ, Malni RN, Feldmann M, Long-Fox A, Charles $\mathrm{P}, \mathrm{Bijl} \mathrm{H}$, et al. Repeated therapy with monoclonal antibody to tumour necrosis factor alpha (cA2) in patients with rheumatoid arthritis. Lancet 1994;344:1125-7.

21 Maini RN, Breedveld FC, Kalden JR, Smolen JS, Davis D, Macfarlane JD, et al. Therapeutic efficacy of multiple intravenous infusions of anti-tumor necrosis factor $\alpha$ monoclonal antibody combined with low dose weekly methotrexate in rheumatoid arthritis. Arthrits Rheum 1996;41:155264.

22 Van De Putte L, Van Riel P, Den Broeder A, Sander O, Rau $\mathrm{R}$, Binder $\mathrm{C}$, et al. A single dose placebo controlled phase I study of the fully human anti TNF antibody D2E7 in study of the fully human anti TNF antibody

23 McCabe D, Moreland L, Caldwell J, Sack M, Weisman M, Edwards CK. A phase 1/11 study to evaluate the safety, immunogenicity pharmacokinetics and potential efficacy of IV rhuTNF binding protein pegylated dimer in patients with active RA. Arthritis Rheum 1996;41:S58

24 Moreland LW, Baumgartener SW, Schiff MH, Tindall EA, Fleishmann RM, Weaver AL. Optimal dose of TNF receptor (p75) fusion protein (ENBREL). Arthritis Rheum 1996;41:S59

25 Abraham E, Glauser MP, Butler T, Garbino J, Gelmont D, Laterre PF, et al. $\mathrm{p} 55$ Tumor necrosis factor receptor fusion protein in the treatment of patients with severe sepsis and septic shock. A randomized controlled multicenter trial JAMA 1997;277:1531-8.

26 Abraham E, Wunderink R, Silverman H, Perl TM, Nasraway S, Levy $\mathrm{H}$, et al. Efficiency and safety of mosraway $\mathrm{S}$, Levy $\mathrm{H}$, et al. Efficiency and safety of patients with sepsis syndrome. JAMA 1995;273:934-41

27 Manogue KR, Van Devanter SJH, Cerami A. Tumor necrosis alpha. In: Thomson AW, ed. The cytokine handbook. sis alpha. In: Thomson AW, ed. The cyto

28 Lorenz HM, Antoni C, Valerius T, Repp R, Grunke M, Schwerdtner N, et al. In vivo blockade of TNF-alpha by intravenous infusion of a chimeric monoclonal TNF-alpha antibody in patients with rheumatoid arthritis. Short term cellular and molecular effects. J Immunol 1996;156:164653.

29 Paleolog EW, Hunt M, Elliott M, Feldmann M, Maini RN, Woody J. Deactivation of vascular endothelium by monocloinal anti tumor necrosis factor a antibody in rheumatoid arthritis. Arthritis Rheum 1996;39:1082-91.

30 Moreland LW, Bucy RP, Weinblatt ME, Garrison L, Agosti JM. Effects of TNF receptor (p75) fusion protein (ENBREL) on immune function. Arthritis Rheum 1996; 41:S59.
31 Weisman M, Wijk A, Zaug M, Durrwell L, Van Der Auwera $\mathrm{P}$, Stevens RM. TNF neutralization does not cause auto-antibodies changes: experience with 247 patients enrolled into a 12 week DB subcutaneous LENERCEPT trial. Arthritis Rheum 1996;41:S85.

32 Tak PP, Taylor PC, Breedveld FC, Smeets TJ, Daha MR, Kluin PM, et al. Decrease in cellularity and expression of adhesion molecules by anti-tumor necrosis factor alpha monoclonal antibody treatment in patients with rheumatoid arthritis. Arthritis Rheum 1996;39:1077-81.

33 Jorgensen C, Couret I, Canovas F, Brochier J, Lipsky P, Sany J. Mononuclear cell retention in rheumatoid synovium engrafted on SCID mice is up regulated by TNFa and mediated through ICAM-1. Clin Exp Immunol 1996; 106:20-6.

34 Firestein GS, Boyle Dl, Yu C, Paine MM, Whisenand TD, Zvaifler NJ, et al. Synovial interleukin-1 receptor antagonist and interleukin- 1 balance in rheumatoid arthritis. Arthritis Rheum 1994;37:644-52.

35 Satoskar A, Okano M, Connaughton S, Raisanen-Sokolwski A, David JR, Labow M. Enhanced Th2 like responses in IL-1 type 1 receptor deficient mice. Eur J Immunol 1998; 28:2066-74.

36 Arend W, Dayer JM. Cytokines and cytokine inhibitors or antagonists in rheumatoid arthritis. Arthritis Rheum 1990; 33:305-15.

37 Joosten LA, Helsen MM, Van De Loo FA, Van Den Berg WB. Anticytokine treatment of established type II collageninduced arthritis in DBA/1 mice. A comparative study using anti-TNF alpha, anti-IL-1 alpha/beta, and IL-1 Ra. Arthritis Rheum 1996;39:797-809.

38 Fisher CJ Jr, Dhainaut JF, Opal SM, Pribble JP, Balk RA, Slotman GJ, et al. Recombinant human interleukin 1 receptor antagonist in the treatment of patients with sepsis syndrome. Results from a randomized, double-blind, placebo-controlled trial. JAMA 1994;271:1836-43.

39 Campion GV, Lebsack ME, Lookabaugh J, Gordon G, Catalano $M$. Dose-range and dose-frequency study of recombinant human interleukin-1 receptor antagonist in patients with rheumatoid arthritis. Arthritis Rheum 1996; 39:1092-101.

40 Weckmann AL, Alcocer-Varela J. Cytokine inhibitors in autoimmune disease. Semin Arthritis Rheum 1996;26: 539-57.

41 Nuki G, Rozman B, Pavelka K, Emery P, Lookabaugh J, Musikic P. IL-1ra continues to demonstrate clinical improvement in rheumatoid arthritis. Arthritis Rheum 1997;40:S224.

42 Dinarello CA. Interleukin-1. In: Thomson AW, ed. The cytokine handbook. London: Academic Press, 1991:47-83.

43 Dreviow B, Capezio J, Lovis R, Jacobs C, Landay A, Pope RM. Phase I study of recombinant human IL1 receptor administered intraarticularly in active rheumatoid arthritis. Arthritis Rheum 1993;36:S39.

44 Dreviow BE, Lovis R, Haag MA, Sinacore JM, Jacobs C. recombinant human IL-1 receptor type 1 in the treatment of patients with active rehumatoid arthritis. Arthritis Rheum 1996;39:257-65.

45 Oshima S, Saeki Y, Mima T, Sasai M, Nishioka K, Nomura $\mathrm{S}$, et al. Interleukin 6 plays a key role in the deleopment of antigen induced arthritis. Proc Natl Acad Sci USA 1998;95:8222-6.

46 Wendling D, Racadot E, Widjenes J. Treatment of severe rheumatoid arthritis by anti-interleukin 6 monoclonal antibody. J Rheumatol 1993;20:259-62.

47 Jorgensen C, Gay S. Gene therapy in osteoarticular disease: where are we? Immunology Today 1998;19:383-430.

48 Walmsley M, Katsikis PD, Abney E, Parry S, Williams RO, Maini RM, et al. IL10 inhibition of the progression of established collagen induced arthritis. Arthritis Rheum 1996;39:495-503. 